\title{
PENGARUH KEPALA SEKOLAH DALAM PENGELOLAAN PENDIDIKAN DI SEKOLAH DASAR
}

\author{
Mevi Tasya Mevlevi ${ }^{1}$, Prihartini ${ }^{2}$, Kuswanto ${ }^{3}$ \\ Pendidikan Guru Sekolah Dasar, Universitas Pendidikan Indonesia ${ }^{1,2,3}$ \\ Email: Mevitasyam@upi.edu
}

\begin{abstract}
Abstrak
Dalam lingkup organisasi satuan pendidikan pada sekolah dasar dibutuhkan peran kepala sekolah. Namun fakta di lapangan yang berperan sebagai kepala sekolah hanya memburu jabatan dan kurang mahir dalam pengelolaan. Padahal sebagai pemimpin memiliki peran yang berpengaruh terhadap kinerja guru dan mutu sekolah. Penulis bertujuan untuk memaparkan peran kepala sekolah serta perlunya pengelolaan pendidikan dengan menggunakan metode deskriptif melalui membaca buku dan jurnal yang mendapatkan hasil bahwa ada pegaruh kepala sekolah dalam pengelolaan pendidikan di sekolah dasar bagi kinerja guru dan hasil pembelajaran.
\end{abstract}

Kata Kunci : Peran Kepala Sekolah, Sekolah Dasar, Pengelolaan Pendidikan

\begin{abstract}
Within the scope of the educational unit organization in elementary schools, the role of principal is needed. However, the fact is that the school principal only hunts for positions and is less proficient in management. Even though as a leader has a role that affects teacher performance and school quality. The authors aims to describe the role of the principal and the need for education management by using descriptive method through reading books and journals, it was found that the principal had an influence in the management of education in primary schools for teacher performance and learning outcomes.
\end{abstract}

Key Words : the Role of the Headmaster, Primary School, Education Management

\section{PENDAHULUAN}

Pendidikan merupakan salah satu wadah untuk bisa mengembangkan dan mengelola sumber daya manusia untuk masa depan Indonesia lebih baik. Karena itu setiap anak mempunyai hak dan kewajiban untuk mendapatkan pendidikan di jenjang sekolah dasar. Tak hanya itu, peserta didik perlu mendapatkan pembelajaran yang berkualitas dan kinerja guru yang baik, maka untuk itu peran kepala sekolah sebagai pemimpin menjadi penggerak yang memiliki kendali dalam menentukan sebuah keberhasilan sekolah.

Seseorang yang dipilih menjadi kepala sekolah ialah seorang guru yang terbaik di antara guru yang lainya karena berkompeten dan menguasai pembelajaran bahkan dapat dikatakan mahir dalam pengelolaan kelas maupun pembelajaran. Dengan demikian figur guru seperti itu pantas untuk menjadi panutan bila menjadi kepala sekolah. Namun terkadang masih ada yang hanya sekedar memburu jabatan atau kurang mahir dalam pengelolaan pendidikan.

Tujuan penulisan artikel ini ialah untuk menyampaikan bahwa ada pengaruh dari kepala sekolah dalam pengelolaan pendidikan pada sekolah dasar. Selain itu, figur kepala sekolah menjadi pemimpin yang memiliki peran penting. Kepemimpinan merupakan sebuah proses yang memberikan pengaruh di dalam suatu kegiatan pada tingkah laku seseorang dan kelompok untuk menggapai tujuan yang sama secara bersama-sama [1].

Pengaruh kepemimpinan adalah kekuatan yang diatributkan karena sebagai pemimpin memiliki kekuatan dan kekuasaan, maka dengan hal demikian seseorang menaruh rasa percaya pada kekuatan tersebut bahwa itu akan bisa 
memberikan manfaat bagi mereka atau tidak, dengan cara tertentu [2].

Karena kepala sekolah sebagai pusat yang dapat menggerakan dan mengendalikan, maka dalam pengelolaan pendidikan yang dirancang dapat memberikan pengaruh pada organisasi satuan pendidikan tersebut, seperti kinerja guru, hasil pembelajaran serta mutu sekolah. Salah satu definisi pengaruh yang terbaik muncul akhir-akhir ini adalah bergerak. Seseorang akan bergerak berubah dan mengambil tindakan jika mereka merasa akan menjadi lebih baik. Semakin baik setelah itu, maka mereka semakin terbuka untuk terpengaruhi [2].

Ada sebuah teori ABC menurut Brian Tracy "antecedants" yang artinya pendahulu yang menggambarkan keadaan sebelum berjumpa serta memberi pengaruh/terpengaruh; B "behavior" yaitu perilaku yang akan dilakukan; serta $\mathrm{C}$ "consequences" yaitu konsekuensi. Jadi, formula dari teori ini $15 \%$ adalah tindakan seseorang akan ditentukan oleh pendahulu, peristiwa sebelumnya dan $85 \%$ adalah motivasi seseorang untuk bisa berubah dan melakukan sesuatu yang akan datang berasal dari antisipasi konsekuensi. Dapat disimpulkan bahwa seseorang hanya akan berubah atau bergerak untuk mengambil tindakan atau dipengaruhi apabila mereka merasa yakin bahwa akan menjadi lebih baik setelah itu, maka mereka akan semakin terbuka untuk menerima pengaruh dalam bentuk apapun [2].

Kemudian ada pengaruh pada konteks kepemimpinan dalam pendidikan ada supervisi yang perlu dilaksanakan oleh kepala sekolah untuk memperbaiki pengelolaan sekolah dalam meningkatkan kinerja pendidik guna menjalankan tugas. Namun ada beberapa alasan menagapa membutuhkan supervisi pendidikan di antaranya :
1. Agar selalu ada inovasi pada perkembangan kurikulum.

2. Untuk adanya peningkatan kompetensi professional.

3. Untuk adanya inovasi pembelajaran guna mengembangkan kualitas kinerja lembaga pendidikan.

Pada bab VI pasal 15, ringkasan garis besar ialah :

1. Melaksanakan tugas pokok manajerial.

2. Mengembangkan sekolah serta meningkatkan mutu sekolah berdasarkan pada 8 standar nasional pendidikan.

3. Melaksanakan tugas pembelajaran dan pembimbingan di sekolah yang dipimpin apabila kekurangan guru, tugas pembelajaran dan pembimbingan tersebut merupakan tugas tambahan di luar tugas pokoknya.

4. Melaksanakan promosi kebudayaan Indonesia kepada SILN [3].

Kompetensi yang perlu kepala sekolah penuhi yaitu kompetensi kepribadian, kompetensi supervisi, kompetensi manjer organisasi dan kompetensi sosial [4].

\section{METODE}

Ditengah kondisi yang sedang pandemi ini, penulis mencoba mencari data dengan metode Studi literatur yaitu dengan membaca dari beberapa buku di antaranya dengan judul pengelolaan pendidikan, seni mempengaruhi orang serta e-book kepemimpinan sekolah dan pengaruhnya terhadap kinerja guru dalam mendongkrak prestasi siswa.

Selain itu, penulis juga melakukan kajian literature melalui beberapa tulisan hasil studi yang menggunakan pendekatan kuantitatif atau kualitatif untuk mengetahui bagaimana kebenaran data yang ada di beberapa sekolah dasar mengenai pengaruh kepala sekolah. 
HASIL DAN PEMBAHASAN

Perlunya penerapan pengelolaan pendidikan (POAC) bagi kepala sekolah.

Management merupakan proses yang memiliki ciri khas meliputi perencanaan, pengorganisasian, penggerakan dan juga pengendalian kinerja dalam menentukan dan juga mencapai sebuah tujuan yang sudah ditetapkan melalui sebuah pemberdayaan sumber daya manusia [4]. Berdasarkan dari pengertian tersebut terdapat rumusan yang menyebutkan langsung adanya fungsi-fungsi dari manajemen yaitu planing atau perencanaan, pengorganisasian atau organizing pengerahan atau pengkoordinasian pergerakan atau actuating dan juga pengontrolan atau controlling performance yang disingat dengan POAC (planing, organization, actuating dan controlling performance). Berikut proses pengelolaan pendidikan menurut James A. F stoner [5].

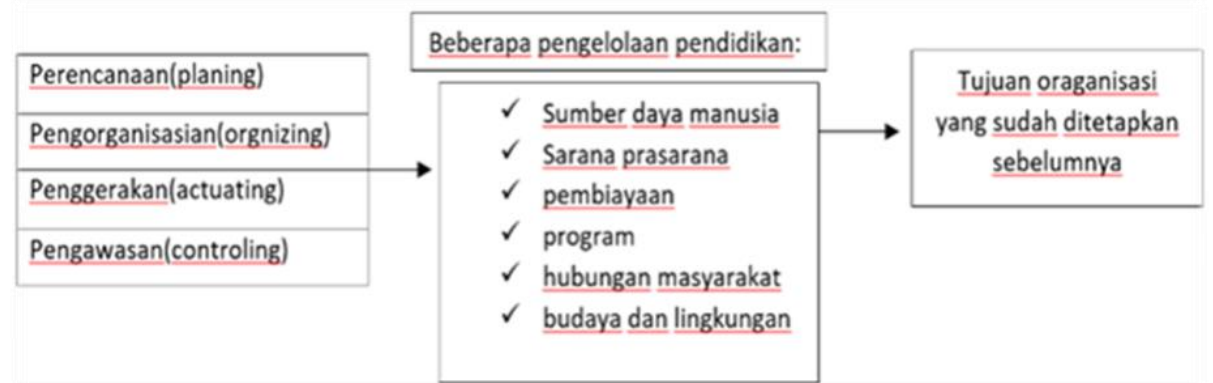

Gambar 1. Skema POAC

Pengelolaan sebagai profesi merupakan sebuah kegiatan pekerjaan yang dikelola oleh seseorang yang memiliki aturan dengan jelas dan latar belakang pendidikan dan juga potensi yang dimiliki ada kalimat yaitu the right man on the right place artinya seseorang sebagai pengelola harus bertanggung jawab dengan pekerjaannya yang melakukan pengelolaan agar mendapatkan hasil yang efisien dan juga efektif untuk mendapatkan tujuan. Hal tersebut sesuai dan bisa diterapkan oleh kepemimpinan kepala sekolah dalam menerapkan pengelolaan dalam satuan pendidikan. Selanjutnya sebagai kepala sekolah telah ditetapkan bahwa terdapat 8 fungsi kepala sekolah sebagai manajer di antaranyanya sebagai mediator, harus berpikir secara analitik serta konsepsional, kepala sekolah sebagai diplomat, bisa mengambil sebuah keputusan yang sulit, bertanggung jawab, harus mampu menghadapi berbagai hal atau persoalan dan mampu bekerja sama dengan orang lain [4]. Kepala sekolah disebut sebagai staf karena lingkungan organisasi pendidikan lebih luas namun kepala sekolah masih berada di bawah kepemimpinan pejabat seperti kepala bidang atau kepala dinas pendidikan, maka sebagai kepala sekolah perlu memiliki loyalitas yang tinggi kemudian memiliki perilaku yang baik.

Ada beberapa perilaku yang bisa diterapkan oleh kepala sekolah yaitu perlunya berinovasi untuk mencari cara baru agar bisa maju, membuat skala prioritas, bisa membagi waktu, memiliki strategi dan perfectif, menjadi brainpower dari pemimpin bukan sebagai pengambil keputusan atau sekedar memberi perintah dan memberikan informasi mengenai sebab akibat terjadinya suatu tindakan [4].

Kualitas pembelajaran

Guru memiliki peran dalam menentukan berhasil atau tidaknya dari hasil pengelolaan pembelajaran. Dalam undangundang nomor 14 tahun 2005 dalam bab 1 pasal 1 menyatakan bahwa guru 
merupakan seorang pendidik yang profesional dengan memiliki tugas utama yaitu mendidik mengajar membimbing mengarahkan melatih menilai dan mengevaluasi peserta didik dalam pendidikan anak usia dini melalui jalur pendidikan formal, pendidikan dasar dan pendidikan menengah [6].

Ada beberapa kemampuan dasar yang perlu dimiliki oleh guru, di antaranya:

Guru harus mengetahui serta menguasai kurikulum. Karena kurikulum adalah hal terpenting untuk keseluruhan dalam program pendidikan sebagai bahan dan bekal untuk pengajaran ke depannya, maka guru harus memahami dan mengetahui seperti apa kurikulum untuk merancang sebuah program pembelajaran. Selain itu, guru dapat dikatakan berhasil dan berprestasi apabila bisa mencapai tujuan dan berhasil mengantarkan siswa kepada tujuan yang sudah ditetapkan.

Guru menguasai materi untuk bahan pembelajaran dan juga menguasai metode serta teknik dalam penilaian merupakan hal yang tidak kalah pentingnya untuk dikuasai karena ilmu yang telah guru tempuh dan guru pelajari harus disampaikan dan ditransfer kepada siswa dan harus bisa membantu perkembangan siswa serta agar siswa dapat menguasai ilmu tersebut. Dalam penyampaian materi tersebut perlu untuk menguasai terlebih dahulu metode yang tepat dan efektif agar lebih maksimal dalam penyampaian materi dan siswa dapat secara aktif ikut terlibat, serta berinteraksi saat proses belajar mengajar dan guru dapat mengevaluasi hasil yang telah siswa kerjakan.

Sebuah proses dapat dikatakan berhasil bila memiliki mutu yang baik di dalam dunia pendidikan, serta apabila pengelolaannya juga baik. Input di dalam sekolah yaitu siswa, guru, sarana prasarana, kurikulum dan yang lainnya. Jika dilakukan dengan harmonis, maka akan mampu menciptakan sebuah keadaan yang lebih konduktif. Dengan demikian kondisi tersebut bisa memberdayakan siswa atau peserta didik [6].

Ada beberapa penelitian yang relevan dengan pengaruh kepala sekolah dalam penerapan pengelolaan pendidikan di sekolah dasar di antaranya :

Pertama, mengenai peran kepemimpinan kepala sekolah dan peningkatan kualitas belajar di SDN 5 terara Lombok Timur [7]. Penelitian ini menyimpulkan bahwa pembelajaran dapat ditingkatkan dengan menggunakan POAC, guna menyelesaikan beberapa permasalahan yang ada di sekolah tersebut. Sekolah yang letaknya kurang strategis atau terpencil tidak membuat kepala sekolah menyerah dengan keadaaan. Masalah yang telah diatasi pertama, pengaruh kedisiplinan, kehadiran kepala sekolah kerap kali tidak sesuai waktunya yang berpengaruh pada kehadiran guru juga siswa yang mengakibatkan ketidaknyamanan serta pembelajaran yang kurang kondusif. Oleh karena itu, kepala sekolah menyadari dengan mengambil keputusan untuk menempati rumah dinas agar memudahkan operasional menuju sekolah. Selain itu, memilih perwakilan siswa kelas 4,5,6 untuk menjadi ketua kedisplinan atau keamanan guna membiasakan kedisiplinan. Hasilnya memang tidak cepat, membutuhkan waktu dan proses. Namun demikian, berhasil meningkatkan kedisiplinan mulai dari guru dan siswa yang tidak lagi saling menunggu kehadiran satu sama lain dan pembelajaran menjadi kondusif. Hal tersebut sejalan dengan yang dipaparkan dalam buku kepemimpinan sekolah dan pengaruhnya terhadap kinerja guru, bahwa pendisiplinan merupakan pekerjaan pengelolaan, namun kepsek harus bisa memimpin sekolah dan juga menjadi pusat hubungan dan juga interpersonal. Hal yang bermasalah dengan kedisiplinan bisa terjadi karena adanya 
permasalahan dengan keluarga, teman atau bahkan dengan guru. Oleh karena itu, walaupun rumit mau tidak mau kepala sekolah harus mampu menanganinya [8].

Kedua, berkenaan dengan sarana prasarana yang perlu pembaharuan, diperbaiki serta ditambahkan. Semangat tinggi siswa dalam kegiatan belajar terasa kurang terfasilitasi dengan sempurna karena kadaan kelas atau meja kursi yang kekurangan. Maka kepala sekolah dengan pengelolaan dan berkesan cukup kompeten berusaha untuk mendapatkan anggaran BOS agar sarana prasarana untuk siswa dapat menjadi lebih layak. Dengan hal-hal tersebut, kepala sekolah telah berusaha untuk menggapai mutu sekolah meskipun tidak dipaparkan secara detail, namun penulis dapat menilai adanya upaya bahwa pada beberapa hal dalam menyelesaikan masalah seperti kedisiplinan, sarana prasarana dan anggaran termasuk upaya yang dilakukan guna meningkatkan kinerja guru, pembelajaran siswa dan mutu sekolah. Walau dengan rintangan dan permasalahan yang ada, kepala sekolah telah berhasil dan mampu mengelola dengan menggunakan POAC, hal-hal yang sudah dilakukan memberikan pengaruh pada kinerja guru dan pembelajran siswa.

Penelitian kedua, tentang peran kepala sekolah dalam pengembangan manajemen sekolah di SD Islam Excellent Bukittinggi [9]. Pada penelitian ini, kepala sekolah sama-sama menggunakan pengelolaan POAC untuk mendapatkan hasil yang optimal dalam menjalankan tugasnya sebagai pimpinan. Berbagai hal dilakukan guna meningkatkan mutu pada segala aspek. Mulai dari kurikulum yang disesuaikan dengan visi dan keterpaduan dengan materi umum, serta pembelajaran mendalam mengenai agama. Kemudian, menambahkan tenaga ahli untuk kebutuhan mengajar dan memberikan fasilitas bagi para pengajar agar bisa mengembangkan potensinya seperti pelatihan, kegiatan kerja guru dan lainnya. Hal tersebut dilakukan guna meningkatkan kualitas dan kinerja guru dalam mengajar. Selain itu, dalam hal sarana prasarana dirasa cukup lengkap disediakan agar menjadi tempat yang nyaman dan aman bagi para peserta didik untuk memanfaatkannya. Hal lainnya berupa hubungan dengan masyarakat pun terjalin dengan baik seperti mengadakan acara khataman para siswa dan mengundang masyarakat sekitar atau melibatkan siswa pada kegiatan membagikan sembako bersama pada masyarakat yang membutuhkan. Beberapa hal tersebut merupakan pengelolaan yang telah dilakukan oleh kepala sekolah untuk bisa membangun pendidikan yang berkualitas dan diminta oleh masyarakat. Kepala sekolah di samping menjadi pemimpin dalam organisasi namun sekaligus juga menjadi manajer yang dapat mengatur dalam segala pengelolaan pada lembaga pendidikan. Berdasarkan hal tersebut, upaya yang telah dilakukan oleh kepala sekolah dapat dikatakan baik dan dapat dijadikan contoh karena bisa memberikan pengaruh pada kinerja guru dan hasil pembelajaran siswa serta proses mencapai mutu sekolah bisa dilakukan dengan baik.

\section{Peningkatan Mutu di Dalam Sekolah}

Berdasarkan dari penjelasan tersebut, maka mutu pendidikan dari sekolah memiliki hubungannya dengan konsep kinerja. Pengelolaan dalam peningkatan mutu di dalam sekolah menjadi salah satu alternatif pada program desentralisasi pada bidang pendidikan dengan adanya sebuah otonomi yang cukup luas pada tingkatan sekolah, karena membuat hubungan masyarakat, kemudian adanya kebijakan dari pendidikan nasional. Otonomi ini diperoleh oleh sekolah untuk mendapatkan keleluasaan dalam jam pengelolaan sumber daya serta dapat menyesuaikan dengan 
prioritas kebutuhan sekolah bisa digunakan dengan maksimal dan tepat.

Selain dari butuhnya hubungan masyarakat agar dapat mengecek serta membantu berjalannya pengelolaan pendidikan, adapun otonomi untuk pengelolaan seperti meningkatkan kinerja dari pendidik dan tenaga kependidikan serta staf yang lainnya kemudian memberikan tawaran kepada kelompok tersebut untuk berpartisipasi dalam meningkatkan pemahaman masyarakat pada pendidikan, dan otonomi yang dimiliki oleh sekolah memiliki peran untuk mengumpulkan atau menjadi wadah konsensus umum dalam memberikan keputusan tersebut oleh mereka yang bertanggung jawab atas pelaksanaan dalam kebijakan ini, serta mereka yang mendapatkan akibat dari kebijakan itu.

\section{SIMPULAN}

Dari berberapa hal yang telah disampaikan bahwasanya dalam kepemimpinan kepala sekolah apabila berkompenten, memiliki kesadaran, kepekaan untuk peningkatan kualitas serta dapat menjalankan pengelolaan dengan baik, seperti menggunakan POAC ini dapat memberikan hasil yang baik pula dan optimal. Selain itu, kepala sekolah yang mefasilitasi guru dengan berbagai macam wadah untuk mengembangkan diri, menambah pengaruh pada hasil kinerja guru dan pengaruh juga pada hasil pembelajaran siswa.

\section{DAFTAR PUSTAKA}

[1] R. Ginting dan T. Haryati. "Kepemimpinan dan Konteks Peningkatan Mutu Pendidikan". J. Ilm. Civ., vol. II, no. 2, pp. 1-17, 2012.

[2] B. Tracy \& Strutzel. Seni Mempengaruhi Orang, 4th ed. Jakarta: Bhuana Ilmu Populer, 2019.
[3] PERATURAN

MENTERI

PENDIDIKAN

DAN

KEBUDAYAAN

REPUBLIK

INDONESIA NOMOR 6 TAHUN

2018.http://lppks.kemdikbud.go.id/u

ploads/pengumuman/1526355089Per mendikbud_Nomor6_Tahun2018.pdf (accessed Feb. 10, 2021).

[4] Prihantini dan T. Rustini. Pengelolaan Pendidikan. Bogor: Pustaka Amma Alamia, 2020.

[5] A. Susanto. "Pengembangan Model Sistem Informasi Manajemen Pendidikan (Research and Development) pada Program Studi Magister Manajemen Pendidikan Pascasarjana Universitas Negeri Jakarta". J. Manaj. Pendidik., vol. 12, pp. 479-487, 2011.

[6] Undang-undang Republik indonesia nomor 14 tahun 2005. https://jdih.usu.ac.id/phocadownload/ userupload/Undang-Undang/UU 142005 Guru dan Dosen.pdf (accessed Feb. 10, 2021).

[7] Nurlaili dan R. E. Bafadal. "Kepemimpinan Kepala Sekolah dan Peningkatan Kualitas Belajar di Sekolah (Studi Kasus SDN 5 Terara Lombok Timur)". Sosio Edukasi (Jurnal Studi Masyarakat dan Pendidikan), vol. 2, no. 1, pp. 27-38, 2018, doi: 10.29408/se.v2i1.358.

[8] H. Hariri, Ridwan, dan D. H. karwan. Kepemimpinan Sekolah dan Pengaruhnya terhadap Kinerja Guru dalam Mendongkrak Prestasi Siswa. Yogyakarta: Graha Ilmu, 2018.

[9] F. Syafrizal. "Peran Kepala Sekolah dalam Pengembangan Manajemen Sekolah sebagai Upaya Meningkatkan Mutu Pendidikan di SD Plus Islam Excellent Bukittinggi”. JMKSP (Jurnal Manajemen, Kepemimpinan, dan Supervisi Pendidikan), vol. 1, no. 2, pp. 65-79, 2017. 